\title{
ANALISIS KINERJA USAHA DAN RISIKO PETAMBAK UDANG VANAME PADA SISTEM TRADISIONAL DAN SISTEM SEMI INTENSIF DI KECAMATAN LABUHAN MARINGGAI KABUPATEN LAMPUNG TIMUR
}

\author{
(Analysis of Farm Performance and Risk of Vaname Shrimp Farmers in the Conventional and Semi- \\ Intensive System in Labuhan Maringgai Subdistrict Lampung Timur Regency)
}

Dewi Sartika Putri, Muhammad Irfan Affandi, Wuryaningsih Dwi Sayekti

Jurusan Agribisnis, Fakultas Pertanian, Universitas Lampung, Jl. Prof. Dr. Soemantri Brojonegoro No.1 Bandar Lampung 35145, Telp. 082279013250,e-mail: irfan.affandi@fp.unila.ac.id

\begin{abstract}
This study aims to analyse the farm performances and the risk of vaname shrimp farmers in conventional and semi-intensive technology in Labuhan Maringgai Subdistrict, East Lampung Regency with the consideration that the location was vaname shrimp production center. The sample in this study were 35 vaname shrimp farmers consisting of 24 conventional farmers and 11 semi-intensive farmers that were randomly selected disproportionately. The research data were collected in March 2019 and analysed using quantitative analysis of farm performance and production risk. The results showed that the farm performance of conventional vaname shrimp farming tended to be better than of the semi-intensive farming. Production risk of conventional vaname shrimp farmers has a higher chance of loss or production risk compared to semi-intensive shrimp farmers.
\end{abstract}

Key words: farm performance, risk, vaname shrimp

\section{PENDAHULUAN}

Perikanan budidaya merupakan salah satu subsektor pembangunan yang sangat potensial untuk menjadi sumber pertumbuhan ekonomi di Indonesia. Secara strategis, perikanan budidaya diharapkan dapat berkontribusi secara nyata dalam mewujudkan kedaulatan pangan, terutama dalam pemenuhan protein yang berkualitas untuk kesehatan, kecerdasan, dan kemakmuran masyarakat (Auliya, Mawardati, dan Suryadi 2018). Badan Pusat Statistik (BPS) mencatat pertumbuhan Produk Domestik Bruto (PDB) Nasional sektor perikanan tahun 2017 sebesar 6,75 persen atau naik sebesar 31 persen dari tahun 2016. Angka PDB tersebut tercatat paling progresif dan berada di atas rata-rata pertumbuhan PDB Nasional yang hanya 5,03 persen (Direktorat Jenderal Perikanan Budidaya 2018).

Menurut Hadijah, Basir, dan Damayanti (2015), pemerintah terus mengupayakan berbagai langkah untuk meningkatkan produktivitas bidang perikanan baik perikanan air tawar, air payau maupun air laut. Diyakini bahwa potensi yang dimiliki masih besar, khususnya perikanan budidaya. Salah satu komoditas perairan air payau yang menjadi prioritas adalah udang. Udang merupakan primadona komoditas perikanan Indonesia, karena potensi sumberdaya komoditas tersebut cukup besar, nilai jualnya tinggi dan peluang pasarnya sangat baik, karena permintaan udang tinggi baik di dalam maupun di luar negeri.

Udang vaname mempunyai beberapa keunggulan dibandingkan dengan spesies lainnya, antara lain tumbuh cepat, toleran terhadap suhu air, tahan terhadap penyakit dan tingkat produktivitas yang tinggi, tersedia teknologi produksi induk atau benih bebas penyakit serta kebutuhan kandungan protein pakan yang relatif rendah (Sudrajat dan Wedjatmiko 2010).

Provinsi Lampung menempati urutan ke empat yang menjadi sentra udang vaname, sehingga berpotensi untuk meningkatkan produksi udang vaname, karena masuk ke dalam lima besar produksi udang vaname di Indonesia. Perkembangan rata-rata poduksi udang vaname di Provinsi Lampung dari tahun 2011-2015 cenderung menurun sebesar 5,02 persen. Produksi udang vaname tersebar di beberapa kabupaten di Provinsi Lampung yang memiliki potensi budidaya tambak udang vaname antara lain Kabupaten Lampung Timur, Lampung Selatan, Tulang Bawang, Pesisir Barat, Tanggamus dan Pesawaran. Hal ini karena beberapa kabupaten tersebut memiliki daerah geografis dan iklim yang mendukung, karena berada di deaerah pesisir pantai (Badan Pusat Statistik 2017). 
Berdasarkan data Dinas Kelautan dan Perikanan Provinsi Lampung (2018), Kabupaten Lampung Timur menempati urutan ke enam sebagai penghasil udang vaname dengan produksi terendah yaitu sebesar $1.481,27 \mathrm{~kg}$ pada tahun 2016 . Hal ini terjadi karena pengusaha tambak udang vaname terkendala oleh keterbatasan modal dan serangan virus WSSV (White Spot Syndrome Virus). Oleh karena itu, perlu ditingkatkan produksinya karena dekat dengan pesisir pantai dan berpotensi tinggi untuk dikembangkannya udang vaname.

Menurut Dinas Perikanan dan Kelautan Kabupaten Lampung Timur (2018), diantara dua kecamatan yang memproduksi udang vaname di Kabupaten Lampung Timur, Kecamatan Labuhan Maringgai memiliki produksi dan produktivitas udang vaname lebih rendah daripada di Kecamatan Pasir Sakti pada tahun 2016 dengan produksi sebesar 1.922,06 ton dan produktivitas 0,68 ton/ha. Rendahnya produksi dan produktivitas di Kecamatan Labuhan Maringgai disebabkan oleh keterbatasan modal dan teknologi. Hal ini sejalan dengan penelitian Susanti, Lestari, dan Kasymir (2017), rendahnya produksi dan produktivitas di bidang perikanan disebabkan oleh pembudidaya yang belum mampu menerapkan teknologi secara optimal, karena harga sarana produksi yang mahal.

Menurut Kementerian Kelautan dan Perikanan Indonesia (2016), keunggulan dari udang vaname teknologi semi intensif adalah memiliki produktivitas lebih tinggi dibandingkan tradisional, karena penggunaan sarana produksi yang lebih modern seperti padat tebar benur, pemberian pakan intensif dan adanya kincir air. Kelemahan teknologi semi intensif membutuhkan biaya yang tinggi, sedangkan keunggulan udang vaname teknologi tradisional memerlukan biaya usaha yang relatif kecil karena lebih mengandalkan faktor alam seperti penggunaan pakan alami. Kelemahan teknologi tradisional adalah menghasilkan produktivitas yang lebih rendah dibandingkan semi intensif, karena mudah terserang penyakit.

Mayoritas pengusaha tambak udang vaname di Kecamatan Labuhan Maringgai menggunakan teknologi tradisional daripada teknologi semi intensif, karena keterbatasan modal yang dimiliki oleh pengusaha tambak, khususnya di Desa Muara Gading Mas Kecamatan Labuhan Maringgai. Selain itu, keterampilan dan pengetahuan pembudidaya terkait udang vaname masih tergolong rendah, karena sebagian besar pengusaha tambak menggunakan saluran keluar masuk air yang menjadi satu, hal tersebut menyebabkan kualitas air menjadi menurun.

Menurut Saragih, Sukiyo, dan Cahyadinata (2015), setiap usaha tidak akan terlepas dari kemungkinan risiko yang dapat menimbulkan kerugian bagi para pelaku usaha. Risiko yang paling mengancam dalam usaha tambak udang disebabkan oleh faktor alam, seperti iklim, cuaca, banjir dan serangan hama penyakit. Udang vaname di Desa Muara Gading Mas Kecamatan Labuhan Maringgai juga terserang penyakit seperti virus WSSV. White Spot Syndrome Virus merupakan penyakit yang paling banyak menimbulkan kerugian secara ekonomi. Penularan WSSV sangat cepat karena dapat menyebabkan kematian 100 persen dalam waktu 310 hari sejak timbul gejala penyakit. Udang vaname yang terkena WSSV dapat menyebabkan risiko gagal panen, sehingga produktivitas udang vaname menurun. Dengan demikian, pengusaha tambak tidak dapat memperoleh keuntungan yang maksimal.

Berdasarkan permasalahan tersebut, maka penelitian ini bertujuan untuk menganalisis kinerja usaha petambak udang vaname, menganalisis risiko produksi usaha petambak udang vaname pada sistem tradisonal dan sistem semi intensif di Desa Muara Gading Mas Kecamatan Labuhan Maringgai Kabupaten Lampung Timur.

\section{METODE PENELITIAN}

Metode yang digunakan dalam penelitian ini adalah metode survei. Penelitian dilakukan di Desa Muara Gading Mas Kecamatan Labuhan Maringgai Kabupaten Lampung Timur. Penentuan lokasi dilakukan secara sengaja (purposive) dengan pertimbangan bahwa menurut Balai Penyuluh Pertanian (BPP) Kecamatan Labuhan Maringgai, Desa Muara Gading Mas merupakan salah satu sentra udang vaname di Kecamatan Labuhan Maringgai Kabupaten Lampung Timur.

Populasi petambak udang vaname sebanyak 250 orang. Pengambilan sampel menggunakan metode sampling acak tak proporsional. Jumlah sampel yang digunakan pada penelitian sebanyak 35 responden. Menurut Nazir (2005), bahwa 30 sampel responden dari populasi yang lebih dari 100 orang dapat mewakili karakteristik responden. Penelitian ini menggunakan 35 responden, berarti lebih dari 30 responden. Responden disengaja melebihi jumlah minimal untuk mengantisipasi adanya data yang tidak valid. Waktu pengumpulan data pada penelitian ini dilaksanakan pada Maret 
2019. Jenis data yang digunakan dalam penelitian ini adalah data primer dan data sekunder. Metode pengumpulan data yang digunakan adalah wawancara, observasi dan pencatatan.

Metode analisis yang digunakan untuk menjawab tentang kinerja usaha adalah metode analisis kuantitatif dan kualitatif. Metode analisis yang digunakan untuk menjawab tentang risiko produksi adalah metode kuantitatif.

Analisis kinerja usaha dilakukan untuk melihat hasil kerja dari petambak udang vaname yang dilihat dari aspek produktivitas, pendapatan atau R/C dan kualitas (Prasetya dan Fitri 2009). Penggunaan alat analisis kinerja ini sejalan dengan penelitian Sari, Zakaria, dan Affandi (2015).

Produktivitas lahan adalah ukuran hasil bagi antara output suatu sektor dengan input lahan dengan menggunakan rumus (Mutu'ali 2018).

Produktivitas $=\frac{\text { Jumlah Produksi }(\mathrm{Kg})}{\text { Luas Lahan }(\mathrm{HOK})}$

Standar nilai besaran produktivitas usaha udang vaname menurut Kementerian Kelautan dan Perikanan Indonesia (2016), adalah produktivitas udang vaname teknologi tradisional adalah 300$500 \mathrm{~kg} / \mathrm{ha} /$ musim, produktivitas udang vaname teknologi semi intensif adalah 6.000-10.000 $\mathrm{kg} / \mathrm{ha} /$ musim.

Pendapatan diperoleh dengan menghitung selisih antara penerimaan atau total revenue (TR) dan semua biaya atau total cost (TC). Pendapatan dari usaha tambak udang vaname dapat dihitung menggunakan rumus sebagai berikut (Soekartawi 1995) sejalan dengan penelitian Setiani, Zakaria, dan Adawiyah (2015).

$\pi=\mathrm{TR}-\mathrm{TC},=\mathrm{Y} . \mathrm{Py}-(\mathrm{FC}+\mathrm{X} . \mathrm{Px})$

Keterangan :

$\pi \quad$ : Pendapatan $(\mathrm{Rp})$

TR : Penerimaan total usaha udang vaname (Rp)

TC : Biaya produksi total $(\mathrm{kg})$

Py : Harga jual produk per unit $(\mathrm{Rp} / \mathrm{Kg})$

Y : Hasil produksi $(\mathrm{kg})$

FC : Biaya tetap (Rp)

$\mathrm{X} \quad$ : Faktor produksi (input) (satuan)

Px : Harga faktor produksi (Rp)

Untuk mengetahui apakah usaha tambak udang vaname menguntungkan atau tidak, maka digunakan analisis R/C (Return Cost Ratio). R/C yaitu perbandingan antara penerimaan (revenue) dengan biaya (cost) dengan rumus :

$\mathrm{R} / \mathrm{C}=\frac{\mathrm{TR}}{\mathrm{TC}}$.

Dengan Kriteria :

a. Jika $\mathrm{R} / \mathrm{C}<1$, maka usaha tambak udang vaname yang dilakukan belum menguntungkan.

b. Jika $R / C>1$, maka usaha tambak udang vaname yang dilakukan menguntungkan.

c. Jika $\mathrm{R} / \mathrm{C}=1$, maka usaha tambak udang vaname ada di titik impas.

Kualitas pada umumnya diukur dengan tingkat ketidaksesuaian produk atau berdasarkan standar Badan Standarisasi Nasional (2006), yaitu udang segar, bau tidak busuk, tekstur cangkang keras dan warna kulit bening dari produk yang dihasilkan (Prasetya dan Fitri 2009).

Nilai risiko produksi ditentukan dengan ukuran koefisien variasi dan batas bawah (Kadarsan 1995). Hal ini sejalan dengan penelitian Devy, Hasyim, dan Situmorang (2018) dimana pengukuran risiko menggunakan koefisien variasi dan batas bawah.

$\mathrm{CV}=\frac{\mathrm{V}}{\mathrm{E}}$

Keterangan:

E : Hasil yang diharapkan $(\mathrm{kg})$

$\mathrm{V} \quad$ : Simpangan baku (standard deviation)

CV : Koefisien variasi

Penentuan batas bawah untuk mengetahui jumlah hasil terbawah tingkat hasil yang diharapkan, rumus perhitungan batas bawah adalah:

$\mathrm{L}=\mathrm{E}-2 \mathrm{~V}$

Keterangan:

L : Batas bawah produksi

V : Simpangan Baku

E : Hasil yang diharapkan $(\mathrm{kg})$

\section{HASIL DAN PEMBAHASAN}

\section{Budidaya Udang Vaname}

Budidaya udang vaname di Desa Muara Gading Mas Kecamatan Labuhan Maringgai Kabupaten Lampung Timur terdiri dari teknologi tradisional dan teknologi semi intensif. Perbedaan tambak tradisional dan semi intensif menurut Kementerian Kelautan dan Perikanan Indonesia (2016) terletak pada teknologi yang digunakan yaitu pada tambak 
teknologi semi intensif menggunakan teknologi yang lebih modern seperti luasan petakan maksimal 1 ha/petak, padat tebar benur 300.000500.000 benur/ha, penggunaan kincir air minimal 16 kincir air per hektar, pemberian pakan yang lebih intensif yaitu pakan buatan (pelet) dan pakan alami, sedangkan tambak teknologi tradisional memiliki luasan petakan maksimal 0,50-2,00 ha/petak, padat tebar benur 50.000 benur/ha, dan lebih mengandalkan faktor alam serta pakan alami. Budidaya udang vaname baik teknologi tradisional maupun semi intensif di Desa Muara Gading Mas Kecamatan Labuhan Maringgai dilakukan bulan Desember dan dipanen saat umur 3 bulan (Desember, Januari, Februari) atau dalam setahun menghasilkan empat kali musim panen. Rata-rata ukuran udang vaname tradisional maupun semi intensif adalah size 90-100. Budidaya udang vaname tradisional dan semi intensif dilakukan dengan beberapa tahap, dimulai dengan persiapan lahan tambak, pengisian air payau, penebaran benur, pemberian pakan, pengendalian hama penyakit, panen, dan pasca panen.

Menurut Kementerian Kelautan dan Perikanan Indonesia (2016), produktivitas udang vaname teknologi tradisional adalah $300-500 \mathrm{~kg} / \mathrm{ha} / \mathrm{musim}$ dan teknologi semi intensif adalah 6.000-10.000 $\mathrm{kg} / \mathrm{ha} /$ musim. Proses produksi usaha udang vaname teknologi tradisional menggunakan sarana produksi seperti benur, pakan (Samsung atau Irawan), kapur dolomit, pupuk (SP36 dan Mutiara), pestisida (Samponen), dan solar. Usaha udang vaname teknologi semi intensif menggunakan sarana produksi produksi seperti benur, pakan (Samsung atau Irawan), kapur dolomit, probiotik (Super PS dan Super MB), pestisida (Samponen dan Ponpos), solar atau listrik untuk menghidupkan kincir air. Sarana produksi tersebut diperoleh dari kios-kios pertanian yang ada di Desa Muara Gading Mas. Penggunaan sarana produksi udang vaname pada teknologi tradisional maupun teknologi semi intensif per hektar dapat dilihat pada Tabel 1.

\section{Kinerja Usaha Udang Vaname}

\section{1) Produktivitas}

Standar nilai produktivitas menurut Kementerian Kelautan dan Perikanan Indonesia (2016), adalah produktivitas udang vaname teknologi tradisional adalah $300-500 \mathrm{~kg} / \mathrm{ha} / \mathrm{musim}$ dan teknologi semi intensif adalah 6.000-10.000 $\mathrm{kg} / \mathrm{ha} / \mathrm{musim}$. Produktivitas usaha udang vaname teknologi tradisional adalah 515,71 $\mathrm{kg} / \mathrm{ha} /$ musim, maka produktivitas udang vaname sudah baik, sedangkan produktivitas usaha udang vaname teknologi semi intensif adalah 1.679,97 kg/ha/musim, maka produktivitas tersebut belum baik. Hal ini dikarenakan petambak semi intensif tidak menggunakan tebar benur dan penggunaan kincir air yang optimal sesuai anjuran Kementerian Kelautan dan Perikanan Indonesia (2016), yaitu padat tebar benur udang vaname sebesar 300.000500.000 benur/ha dan penggunaan kincir air minimal 16 kincir air per hektar. Penggunaan sarana produksi tambak semi intensif tidak sesuai anjuran Kementerian Kelautan dan Perikanan Indonesia (2016), karena terkendala oleh terbatasnya dana dalam pembelian sarana produksi. Selain itu, usaha udang vaname semi intensif juga terserang penyakit WSSV mencapai 16,67 persen petambak, sehingga mengalami gagal panen.

\section{2) Pendapatan}

Menurut Penelitian Saputra, Prasmatiwi, dan Ismono (2017), petani dalam melakukan usahatani bertujuan untuk memaksimalkan pendapatan. Pendapatan merefleksikan nilai yang diperoleh petani setelah dikurangi dengan biaya usahataninya. Pendapatan yang diterima oleh petambak udang vaname dipengaruhi oleh besarnya penerimaan yang diperoleh dan besarnya biaya total yang dikeluarkan. Analisis pendapatan usaha tambak udang vaname dapat dilihat pada Tabel 1. Berdasarkan data pada Tabel 1, pendapatan usaha udang vaname semi intensif lebih besar daripada usaha udang vaname tradisional. Pendapatan atas biaya total dari udang vaname semi intensif adalah $\mathrm{Rp} 33.837 .069,13 /$ ha/musim. Besarnya nisbah penerimaan terhadap biaya total adalah 1,51 yang berarti setiap Rp1.000.000,00 biaya total yang dikeluarkan petambak udang semi intensif akan menghasilkan penerimaan sebesar Rp1.510.000,00. Pada Tabel 1 terlihat bahwa $\mathrm{R} / \mathrm{C}$ usaha tambak udang tradisional maupun semi intensif $>1$, maka usaha tambak tradisional maupun semi intensif dikatakan menguntungkan, karena nilai $\mathrm{R} / \mathrm{C}>1$.

Hal ini sejalan dengan penelitian Sazmi, Haryono, dan Suryani (2018) yang menghasilkan nilai R/C atas biaya total yaitu 2,06 pada usahatani ikan patin di Kabupaten Lampung Tengah. Selain itu, penelitian ini sejalan juga dengan penelitian Kinanti, Haryono, dan Nugraha (2018) bahwa hasil usaha sayuran yang dihasilkan menguntungkan, karena nilai $\mathrm{R} / \mathrm{C}$ rasio lebih dari satu. 
Tabel 1. Analisis pendapatan usaha tambak udang vaname tradisional dan semi intensif di Desa Muara Gading Mas Kecamatan Labuhan Maringgai Kabupaten Lampung Timur.

\begin{tabular}{|c|c|c|c|c|c|c|c|c|}
\hline \multirow{3}{*}{ No } & \multirow{3}{*}{ Uraian } & \multirow{3}{*}{ Satuan } & \multirow{2}{*}{\multicolumn{3}{|c|}{$\begin{array}{l}\text { Teknologi Tradisional } \\
\text { Luas tambak Per } 1 \text { ha }\end{array}$}} & \multirow{2}{*}{\multicolumn{3}{|c|}{$\begin{array}{c}\text { Teknologi Semi Intensif } \\
\text { Luas tambak Per } 1 \text { ha }\end{array}$}} \\
\hline & & & & & & & & \\
\hline & & & Jumlah & $\begin{array}{c}\text { Harga } \\
(\mathrm{Rp})\end{array}$ & Nilai & Jumlah & $\begin{array}{l}\text { Harga } \\
(\mathrm{Rp})\end{array}$ & Nilai \\
\hline \multirow{32}{*}{2} & Penerimaan & & & & & & & \\
\hline & Produksi & $\mathrm{Kg}$ & 515,71 & $52.490,99$ & $27.069 .871,79$ & $1.679,97$ & $59.270,48$ & $99.572 .727,27$ \\
\hline & Biaya Produksi & & & & & & & \\
\hline & $\begin{array}{l}\text { a. Biaya Tunai } \\
\text { Biaya Variabel }\end{array}$ & & & & & & & \\
\hline & Benur & Ekor & $80.448,72$ & 40,42 & $3.251 .469,02$ & $154.829,55$ & 42,73 & $6.615 .444,21$ \\
\hline & Pakan & $\mathrm{Kg}$ & 566,99 & $12.754,17$ & $7.231 .448,99$ & $2.907,67$ & $14.218,18$ & $41.341 .787,19$ \\
\hline & Dolomit & $\mathrm{Kg}$ & 355,45 & 659,09 & $234.273,02$ & 788,35 & 580,00 & $457.244,32$ \\
\hline & Pupuk & & & & & & & \\
\hline & SP36 & $\mathrm{Kg}$ & 6,41 & $3.750,00$ & $24.038,46$ & & & \\
\hline & Mutiara & $\mathrm{Kg}$ & 9,62 & $7.000,00$ & $67.307,69$ & & & \\
\hline & Probiotik & & & & & & & \\
\hline & 1) Super PS & Liter & & & & 23,44 & $15.071,43$ & $353.236,61$ \\
\hline & 2) Super MB & Liter & & & & 2,84 & $64.750,00$ & $183.948,86$ \\
\hline & Pestisida & & & & & & & \\
\hline & 1) Samponen & $\mathrm{Kg}$ & 29,10 & $15.150,00$ & $440.819,40$ & 41,90 & $13.583,33$ & $569.187,97$ \\
\hline & 2) Ponpos & Liter & & & & 1,85 & $100.000,00$ & $184.659,09$ \\
\hline & BBM (Solar) & Liter & 41,99 & $6.958,33$ & $292.160,79$ & 494,32 & $6.772,73$ & $3.347 .882,23$ \\
\hline & Listrik & $\mathrm{Rp} / \mathrm{MT}$ & & & & & & $5.454 .545,45$ \\
\hline & TKLK & HOK & 11,98 & $100.000,00$ & $1.197 .916,67$ & 29,67 & $100.000,00$ & $2.966 .974,43$ \\
\hline & Biaya Tetap & & & & & & & \\
\hline & PBB & $\mathrm{Rp} / \mathrm{MT}$ & & & $10.985,58$ & & & $10.538,00$ \\
\hline & Sewa Lahan & $\mathrm{Rp} / \mathrm{ha} / \mathrm{MT}$ & & & $172.275,64$ & & & $53.267,05$ \\
\hline & Total Biaya Tunai & $\mathrm{Rp}$ & & & $12.922 .695,25$ & & & $61.538 .715,42$ \\
\hline & b. Biaya Diperhitung & $\operatorname{san}$ & & & & & & \\
\hline & Biaya Variabel & & & & & & & \\
\hline & TKDK & HOK & 25,49 & $100.000,00$ & $2.548 .878,21$ & 27,04 & $100.000,00$ & $2.704 .190,34$ \\
\hline & Biaya Tetap & & & & & & & \\
\hline & Penyusutan & $\mathrm{Rp} / \mathrm{MT}$ & & & $136.424,36$ & & & $747.013,75$ \\
\hline & Sewa Lahan & $\mathrm{Rp} / \mathrm{ha} / \mathrm{MT}$ & & & $479.166,67$ & & & $745.738,64$ \\
\hline & Total Biaya & & & & & & & \\
\hline & Diperhitungkan & $\mathrm{Rp}$ & & & $3.164 .469,23$ & & & $4.196 .942,73$ \\
\hline & c. Total Biaya & $\mathrm{Rp}$ & & & $16.087 .164,48$ & & & $65.735 .658,15$ \\
\hline \multirow{3}{*}{3} & Pendapatan & & & & & & & \\
\hline & Atas Biaya Tunai & $\mathrm{Rp} / \mathrm{MT}$ & & & $14.147 .176,55$ & & & $38.034 .011,85$ \\
\hline & Atas Biaya Total & $\mathrm{Rp} / \mathrm{MT}$ & & & $10.982 .707,31$ & & & $33.837 .069,13$ \\
\hline \multirow[t]{3}{*}{4} & R/C Ratio & & & & & & & \\
\hline & Atas Biaya Tunai & & & & 2,09 & & & 1,62 \\
\hline & Atas Biaya Total & & & & 1,68 & & & 1,51 \\
\hline
\end{tabular}

\section{3) Kualitas}

Produk udang vaname yang berkualitas akan mempengaruhi tingkat penjualan udang vaname ke pasar maupun perusahaan. Udang vaname yang dihasilkan petambak udang vaname baik tradisional maupun semi intensif sudah baik menurut mutu udang segar berdasarkan standar Badan Standarisasi Nasional (2006), yaitu bau tidak busuk dan tekstur cangkang keras dan bening. Udang vaname yang dihasilkan responden diterima di berbagai perusahaan ekspor udang yang ada di dalam maupun di luar Provinsi Lampung
Hal ini sejalan dengan penelitian Sari, Haryono, dan Adawiyah (2017), kualitas kopi bubuk yang dihasilkan di Kota Bandar Lampung sudah baik. Kompilasi kinerja usaha tambak udang vaname baik tradisional maupun semi intensif dapat dilihat pada Tabel 2. Berdasarkan Tabel 2, kinerja usaha udang vaname teknologi tradisional cenderung lebih baik dibandingkan teknologi semi intensif karena pengalaman usaha petambak tradisional lebih lama yaitu rata-rata 3 tahun sedangkan petambak semi intensif terbilang pemula yaitu ratarata hanya 2 tahun, karena teknologi semi intensif baru diterapkan di Kecamatan Labuhan Maringgai. 
Tabel 2. Kompilasi kinerja usaha udang vaname

\begin{tabular}{lcccc}
\hline Komponen & \multicolumn{2}{c}{ Tradisional } & \multicolumn{2}{c}{ Semi Intensif } \\
\cline { 2 - 5 } $\begin{array}{l}\text { Penelitian } \\
\text { Produktivitas } \\
\text { (kg/ha/musim) }\end{array}$ & 515,71 & Baik & $1.679,97$ & $\begin{array}{l}\text { Kurang } \\
\text { Baik }\end{array}$ \\
\hline $\begin{array}{l}\text { Pendapatan } \\
\text { (Rp/ha) }\end{array}$ & $10.982 .707,31$ & Baik & $33.837 .069,13$ & Baik \\
\hline Kualitas & $\begin{array}{l}\text { Udang segar, } \\
\text { cangkang } \\
\text { keras dan } \\
\text { kulit bening }\end{array}$ & Baik & $\begin{array}{l}\text { Udang segar, } \\
\text { cangkang } \\
\text { keras dan } \\
\text { kulit bening }\end{array}$ & Baik \\
\hline
\end{tabular}

\section{Analisis Risiko Produksi}

Risiko produksi terjadi karena adanya fluktuasi produksi udang vaname teknologi tradisional selama lima musim tanam terakhir. Fluktuasi produksi tersebut terjadi disebabkan oleh beberapa faktor, diantaranya faktor cuaca/iklim yang tidak stabil dan adanya serangan penyakit WSSV. Hal ini sejalan dengan penelitian Naftaliasari, Abidin, dan Kalsum (2015), petani dipengaruhi oleh keadaan alam. Berdasarkan penelitian bahwa fluktuasi produksi udang vaname tradisional dapat dilihat pada Gambar 1. Produksi udang vaname terendah selama lima musim tebar benur berada pada MT-4 dengan produksi rata-rata sebesar $154,55 \mathrm{~kg}$ per hektar.

\section{Fluktuasi Produksi Udang Vaname Tradisional}

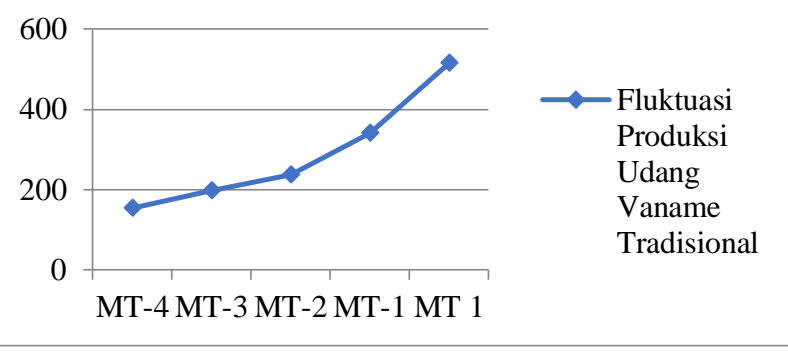

Gambar 1. Fluktuasi produksi udang vaname tradisional $(\mathrm{kg} / \mathrm{ha})$

\section{Fluktuasi Produksi Udang Vaname Semi Intensif}

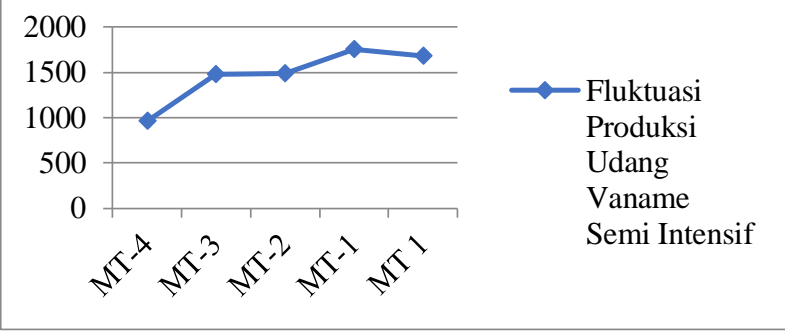

Gambar 2. Fluktuasi produksi udang vaname semi intensif $(\mathrm{kg} / \mathrm{ha})$
Jumlah petambak udang vaname tradisional yang mengalami gagal panen (80-100 persen) di MT-4 adalah 79,17 persen. Hal ini terjadi karena berdasarkan penelitian, MT-4 dilakukan pada bulan Desember-Februari 2018. Pada bulan tersebut, cuaca/iklim tidak stabil yaitu musim hujan yang berkepanjangan, sehingga menyebabkan $\mathrm{Ph}$ air tambak turun dan menyebabkan kualitas air menurun juga. Kualitas air yang menurun menyebabkan udang vaname mudah terserang penyakit WSSV. Udang vaname yang terserang penyakit WSSV akan mengalami kematian hingga 100 persen. Hal ini sejalan dengan penelitian Aini, Prasmatiwi, dan Sayekti (2015), kegagalan panen sering diakibatkan oleh cuaca ekstrim dan hama penyakit.

Fluktuasi produksi udang vaname semi intensif dapat dilihat pada Gambar 2. Produksi udang vaname teknologi semi intensif terendah selama lima musim tebar benur berada pada MT-4 dengan produksi rata-rata sebesar $964,49 \mathrm{~kg}$ per hektar. Jumlah petambak udang vaname semi intensif yang mengalami gagal panen (80-100 persen) di MT-4 adalah 54,55 persen petambak udang vaname. Hal ini terjadi karena berdasarkan penelitian, MT-4 dilakukan pada bulan DesemberFebruari 2018. Pada bulan tersebut, cuaca/iklim tidak stabil yaitu musim hujan yang berkepanjangan, sehingga menyebabkan $\mathrm{Ph}$ air menurun dan udang vaname kehilangan nafsu makan. Dampak dari musim hujan yang berkepanjangan adalah udang vaname dapat mudah terserang penyakit WSSV. Hal ini karena nafsu makannya berkurang, sehingga kekebalan tubuhnya menurun yang menyebabkan udang vaname mudah terserang penyakit WSSV.

Tabel 3 menunjukkan nilai koefisien variasi usaha udang vaname tradisional adalah 0,74 maka usaha tersebut memiliki risiko produksi tinggi, sedangkan nilai koefisien variasi usaha tambak udang semi intensif 0,48 maka usaha tersebut memiliki risiko produksi rendah.

Tabel 3. Analisis risiko produksi usaha tambak udang vaname teknologi tradisional dan teknologi semi intensif (per hektar)

\begin{tabular}{lrr}
\hline \multicolumn{1}{c}{ Keterangan } & \multicolumn{1}{c}{$\begin{array}{c}\text { Nilai } \\
\text { Teknologi } \\
\text { Tradisional }\end{array}$} & $\begin{array}{c}\text { Nilai } \\
\text { Teknologi } \\
\text { Semi Intensif }\end{array}$ \\
\hline Mean (E) & 339,55 & $1.870,15$ \\
Ragam (V2) & $61.880,05$ & $1.142 .098,76$ \\
Simpangan Baku (V) & 222,14 & 750,94 \\
Koefisien Variasi (CV) & 0,74 & 0,48 \\
Batas Bawah (L) & $-104,72$ & 368,27 \\
\hline
\end{tabular}


Hal ini menunjukkan bahwa risiko produksi yang dimiliki petambak udang vaname tradisional lebih tinggi dibandingkan petambak udang vaname semi intensif. Batas bawah (L) produksi yang dihasilkan usaha udang vaname teknologi tradisional adalah $-104,72 \mathrm{~kg} / \mathrm{ha}$, sedangkan pada usaha udang vaname teknologi semi intensif adalah $368,27 \mathrm{~kg} / \mathrm{ha}$. Angka tersebut merupakan risiko yang mungkin ditanggung oleh petambak udang, baik teknologi tradisional maupun teknologi semi intensif.

Menurut Talakua (2014), jika nilai CV >0,50 dan $\mathrm{L}<0$, berarti ada peluang kerugian atau risiko produksi tinggi yang akan dialami produsen, sedangkan jika $\mathrm{CV}<0,50$ dan $\mathrm{L}>0$, maka produsen tidak akan mengalami peluang kerugian atau risiko produksi rendah. Berdasarkan hasil penelitian, petambak udang vaname teknologi tradisional memiliki nilai $\mathrm{CV}>0,50$ yaitu 0,74 dan $\mathrm{L}<0$ yaitu $-104,72$, sehingga memiliki peluang kerugian atau risiko produksi tinggi, sedangkan petambak udang vaname teknologi semi intensif memiliki nilai $\mathrm{CV}<0,50$ yaitu 0,48 dan $\mathrm{L}>0$ yaitu 368,72 sehingga petambak udang vaname teknologi semi intensif memiliki risiko produksi rendah.

Menurut Eprianda, Prasmatiwi, dan Suryani (2017), risiko produksi yang lebih tinggi diakibatkan karena serangan penyakit yang menimbulkan kematian pada tanaman selada keriting. Risiko produksi tambak tradisional lebih tinggi dibandingkan tambak semi intensif karena penyakit WSSV lebih tinggi menyerang tambak udang tradisional dibandingkan tambak semi intensif. Penelitian ini sejalan juga dengan penelitian Talakua (2014), usaha pengolahan ikan cakalang banda di Kecamatan Banda bahwa nilai $\mathrm{CV}<0,50$ dan $\mathrm{L}>0$, maka usaha tersebut tidak memiliki risiko yang tinggi.

\section{KESIMPULAN}

Kinerja usaha tambak udang vaname tradisional cenderung lebih baik dibandingkan usaha tambak udang vaname semi intensif. Risiko produksi udang vaname sistem tradisional memiliki risiko produksi lebih tinggi dibandingkan risiko produksi petambak udang vaname semi intensif di Desa Muara Gading Mas Kecamatan Labuhan Maringgai Kabupaten Lampung Timur.

\section{DAFTAR PUSTAKA}

Aini HN, Prasmatiwi FE, dan Sayekti WD. 2015. Analisis pendapatan dan risiko usahatani kubis pada lahan kering dan lahan sawah tadah hujan di Kecamatan Gisting Kabupaten Tanggamus. JIIA, 3 (1): 1-9. http://jurnal.fp. unila.ac.id/index.php/JIA/article/download/10 11/916 [4 April 2019 ].

Auliya MR, Mawardati, dan Suryadi. 2018. Analisis kelayakan finansial tambak udang vannamei (Studi kasus tambak udang vannamei di Blang Lancang Desa Batuphat Timur Kecamatan Muara Satu, Lhokseumawe). Jurnal Agriprimatech, 1 (2) : 38-44. file:///C:/Users/user/Downloads/Docu ments/172-133-324-1-10-20180814.pdf [10 November 2018 ].

Badan Standarisasi Nasional. 2006. Standar Nasional Indonesia 01-2728.1-2006 : Udang Segar. Badan Standarisasi Nasional. Jakarta.

BPS [Badan Pusat Statistik]. 2017. Statistik Sumber Daya Laut dan Pesisir 2017. Badan Pusat Statistik. Jakarta.

Devy J, Hasyim AI, dan Situmorang S. 2018. Analisis kelayakan finansial dan risiko usaha budidaya jamur tiram di Provinsi Lampung. JIIA, 6 (3) : 347-354 http://repository.lppm. unila.ac.id/12536/1/3050-7431-1-SM.pdf [20 Desember 2019].

Dikretorat Jenderal Perikanan Budidaya. 2018. Capaian Kinerja Subsektor Perikanan Budidaya dan Outlook Tahun 2018. KKP. Jakarta. https://kkp.go.id/djpb/artikel/3042capian-kinerja-subsektor-perikanan-budidayadan-outlook-tahun-2018 [5 November 2018].

Dinas Kelautan dan Perikanan Provinsi Lampung. 2018. Produksi Udang Vaname Kabupaten/ Kota Lampung (Ton) 2013-2017. Dinas Kelautan dan Perikanan Provinsi Lampung. Bandar Lampung.

Dinas Perikanan dan Kelautan Kabupaten Lampung Timur. 2018. Luas Lahan, Produksi, dan Produktivitas Udang Vanname Per Kecamatan Tahun 2017. Dinas Perikanan dan Kelautan Kabupaten Lampung Timur. Sukadana.

Eprianda D, Prasmatiwi FE, dan Suryani A. 2017. Efisiensi produksi dan analisis risiko budidaya selada keriting hijau dan selada romaine hidroponik NFT (Nutrient Film Teqhnque) di PT XYZ Provinsi Jawa Barat. JIIA, 5 (3) : 242-249. http://jurnal.fp.unila.ac.id/index.php/ JIA/article/download/1636/1462 [7 Desember 2019].

Hadijah S, Basir M, dan Damayanti L. 2015. Analisis pendapatan dan strategi pengembangan usaha budidaya ikan nila di Kecamatan Ampana Kabupaten Tojo UnaUna. Jurnal Agroland, 22 (3) : 235-243. 
http://jurnal.untad.ac.id/jurnal/index/php/AGR OLAN/article/view/8797 [28 November 2018].

Kadarsan HW. 1995. Keuangan Pertanian dan Pembiayaan Perusahaan Agribisnis. Gramedia Pustaka. Jakarta.

Kementerian Kelautan dan Perikanan Indonesia. 2016. Peraturan Menteri Kelautan dan Perikanan Republik Indonesia Nomor 75 PERMEN-KP/2016 tentang Pedoman Umum Pembesaran Udang Windu (Penaeus monodom) dan Udang Vaname (Litopenaeus vannamei). KKP. Jakarta.

Kinanti N, Haryono D, dan Nugraha A. 2018. Analisis pendapatan usahatani sayuran di Kecamatan Sumberejo Kabupaten Tanggamus JIIA, 6 (4) : 437-444. http://jurnal.fp.unila. ac.id/index.php/JIA/article/view/3065 [3 Desember 2019 ].

Mutu'ali L. 2018. Dinamika Peran Sektor Pertanian dalam Pembangunan Wilayah Indonesia. Gadjah Mada University Press. Yogyakarta.

Naftaliasari T, Abidin Z, dan Kalsum U. 2015. Analisis risiko usahatani kedelai di Kecamatan Raman Utara Kabupaten Lampung Timur. JIIA, 3 (2) : 148-156. http://jurnal.fp.unila.ac.id/index.php/JIA/articl e/download/1033/938 [Desember 2019].

Nazir. 2005. Metode Penelitian Cetakan Keenam. Ghalia Indonesia. Bogor.

Prasetya H dan Fitri. 2009. Manajemen Operasi. Media Pressindo. Yogyakarta.

Saputra JE, Prasmatiwi FE, dan Ismono RH. 2017. Pendapatan dan risiko usahatani jahe di Kecamatan Penengahan Kabupaten Lampung Selatan. JIIA, 5 (4): 392-398. http://jurnal.fp. unila.ac.id/index.php/JIA/article/download/17 48/1551. [5 Desember 2019.].

Saragih NS, Sukiyo K, dan Cahyadinata I. 2015. Analisis risiko produksi dan pendapatan budidaya tambak udang rakyat di Kelurahan Labuhan Deli Kecamatan Medan Marelan Kota Medan. Jurnal Agrisep, 4 (1) : 39 - 52. https://ejournal.unib.ac.id/index.php/agrisep/a rticle/download/593/534 [Oktober 2018.].
Sari IRM, Zakaria WA, dan Affandi MI. 2015. Kinerja produksi dan nilai tambah agroindustri emping melinjo di Kota Bandar Lampung. JIIA, 3 (1): 18-25. http://jurnal.fp. unila.ac.id/index.php/JIA/article/viewFile/101 3/918 [17 November 2018.].

Sari M, Haryono D, dan Adawiyah. 2017. Kinerja produksi dan strategi pengembangan agroindustri kopi bubuk di Kota Bandar Lampung. JIIA, 5 (4) : 360-367. http://jurnal. fp.unila.ac.id/index.php/JIA/article/download/ 1744/1547 [9 November 2018.].

Sazmi R, Haryono D, dan Suryani A. 2018. Analisis pendapatan dan efisiensi pemasaran ikan patin di Kecamatan Seputih Raman Kabupaten Lampung Tengah. JIIA, 6 (2): 133-141. http://jurnal.fp.unila.ac.id/index.php/ JIA/article/viewFile/2778/2324 [3 Desember 2019.]

Setiani N, Zakaria WA, dan Adawiyah R. 2015. Analisis keuntungan usahatani antar pola tanam lahan sawah Desa Tata Karya Kecamatan Abung Surakarta Kabupaten Lampung Utara. JIIA, 3 (2): 122-129. http://jurnal.fp.unila.ac.id/index.php/JIA/articl e/viewFile/1030/935 [9 Desember 2019].

Soekartawi. 1995. Pembangunan Pertanian. PT Raja Grafindo Persada. Jakarta.

Sudrajat A dan Wedjatmiko. 2010. Budidaya Udang di Sawah dan Tambak. Penebar Swadaya. Jakarta.

Susanti S, Lestari DAH, dan Kasymir E. Sistem agribisnis ikan patin (Pangasius sp) Kelompok Budidaya Ikan Sekar Mina di Kawasan Minapolitan Patin Kecamatan Kota Gajah Lampung Tengah. JIIA, 5 (2): 116123. http://jurnal.fp.unila.ac.id/index.php/JIA/ article/download/1648/1474 [10 Desember 2019 ].

Talakua W. 2014. Analisis pendapatan dan risiko usaha ikan cakalang banda di Kecamatan Banda. Jurnal Omni-Akuatika, 12 (19): 5359. https://ojs3.unpatti.ac.id/index.php/arika/ article/view/404/371 [22 November 2019]. 